\title{
Why are African honey bees and not European bees invasive? Pollen diet diversity in community experiments
}

\author{
Rogel VILlANUEVA-G. ${ }^{\mathrm{a}}$, David W. RouBIK ${ }^{\mathrm{b} *}$ \\ a El Colegio de la Frontera Sur, Apdo. Postal 424, Chetumal, Quintana Roo, Mexico \\ b Smithsonian Tropical Research Institute, Unit 0948, APO AA 34002-0948, USA
}

(Received 29 September 2003; revised 24 December 2003; accepted 19 January 2004)

\begin{abstract}
We studied resource use and competition by varieties of a honey bee, Apis mellifera, through re-introducing European A. m. ligustica in experimental apiaries in a habitat 'saturated' by African (or hybrid African and European) honey bees that naturally colonized forest in the Yucatan Peninsula of Mexico. Over 171 pollen species comprised honey bee diets. The Morisita-Horn similarity index (highest similarity $=1.0$ ) between the two honey bee races was 0.76 for pollen use and, from the average daily volume usage by colonies of each bee subspecies, 0.55 for taxon-specific intensity of use. Although using more plant species, the European bee specialized much more heavily on a few plants than did African honey bees. By re-analysis of pollen pellets collected by locally-adapted (Mexican) European honey bees for one year, at the same experimental sites and using the same pollen traps as our studies, before the arrival of invasive honey bees in S. Mexico, we infer that resident bees may respond to exotic honey bee competition by shifting flower choice and by increasing resource specialization. We also show that replicated, quantitative pollen analysis is a powerful tool that may be applied to understanding diet diversity of bees.
\end{abstract}

Apis mellifera / niche use / diet diversity / pollen / invasive species / competition

\section{INTRODUCTION}

Given the tremendous differences in the abundance of Apis mellifera $\mathrm{L}$. before and after colonization of the neotropics by honey bees from SE Africa (see Clarke et al., 2001; Roubik and Wolda, 2001; Roubik, 2002a, b) a general hypothesis is that the African bees were better adapted as colonists. This study is an effort to characterize one element of honey bee biology in Neotropical forests - diet diversity - which may help to account for the remarkable reproductive and/or survival capability of the invasive tropical honey bee and its hybrids. No previous work has quantified differences that may exist in flower use by resident European apiary bees and feral Africanized honey bees which replace them. However, several studies, including our unpublished observations, demonstrate that African bee colonies harvest pollen more intensively than European colonies in the same habitat (Fewell and Bertram, 2002).

Some melissopalynological research has been undertaken in African countries, using a very small number of samples, and there also are lists of pollen species found in honey, or made from field observations at flowers (e.g. Smith, 1956; Banda, 1989; Ricciardelli D'Albore and Owusu, 1994; see also Hepburn and Radloff, 1998). Such studies, and similar work in the neotropics (Roubik et al., 1984; Ramalho et al., 1990; Wilms et al., 1996) form a partial view of resources used by the African honey bees. More studies are required to cover large

\footnotetext{
* Corresponding author: roubikd@ tivoli.si.edu
} 
areas of natural vegetation, with a greater number of samples, and more importantly, with greater precision of pollen identification. Studies performed in lowland forest in Panama revealed 45-79 major pollen species used during one year by African or Africanized bees (Roubik et al., 1984). Beyond this preliminary work, there is no characterization of diet niche in wild tropical honey bees, with perhaps the exception of southeast Asia (Roubik, 2005), and no scientific means for predicting the niche use or spread of invasive bees (but see Southwick et al., 1990; Goulson, 2003; Peterson, 2003).

Competition for floral resources often causes changes that involve behavior and nontaxonomic niche dimensions -intensity of use, resource defense, or preference - seldom quantified in large-scale studies (Rosenzweig, 1995; Tokeshi, 1999; Agrawal, 2001). African honey bees created the first feral populations of Apis in tropical America (Roubik, 1989, 2002a, b; Roubik and Wolda, 2001; Dick, 2001). Here we explore competition between consumers that are normally termed generalists, but which nonetheless display temporal specialization in resource use (Roubik, 1992). Successful invasive species are thought to out-compete resident species by exploiting more resources than they do (Sakai et al., 2001). Making use of the wide-scale accidental naturalization of honey bees, we document niche dynamics of competing pollinators during two continuous years in a post-colonization, tropical environment.

\section{MATERIALS AND METHODS}

\subsection{Study area and rationale}

In the semi-deciduous forest of Sian Ka'an Biosphere Reserve, Quintana Roo, Mexico (19.6 $\left.{ }^{\circ} \mathrm{N}\right)$, and in a nearby locale our study took place in 198691, during which no change (e.g. clearing, fires) in nearby vegetation occurred (Villanueva-G., 1994, 1999, 2002).

Even widespread, intensive beekeeping with European honey bees in Yucatan did not prevent rapid genetic assimilation by African honey bees. Interbreeding made local Apis mellifera progressively more African (Clarke et al., 2001, 2002). Thirty colonies of European bees were therefore re-introduced to apiaries in 1989-91 where African Apis mellifera scutellata Lepeletier and feral hybrids became well established in 1987 (Villanueva-G., 1994, 1999, 2002).
Mated queens and their European colonies of A. mellifera ligustica Spinola were imported from Hawaii. Another 30 colonies of feral 'Africanized' honey bees were collected locally, not in apiaries, and placed in hives. Bee colonies of the two races studied were similar in size, generally calibrated from comb number and hive weight, within one or two standard Langstroth hive bodies.

We established two study sites, one within the half-million hectare Sian Ka' an Biosphere Reserve and one $10 \mathrm{~km} \mathrm{~S}$. of the reserve, within a more disturbed forest which included small agricultural plots, at Palmas. The experimental hives were fitted with pollen traps, which remove pollen loads from the hind legs of returning foragers (see VillanuevaG., 1999, 2002). Incoming pollen was sampled for one full day each month from June, 1989 until May, 1991. During one year at Sian Ka'an and two years at Palmas, pollen was taken each month from 3 of the 15 colonies, chosen randomly. Thus, three colonies of each honey bee race at a site were sampled each month.

Comparative data for locally-adapted, hived honey bees (smaller, by standard morphometric measurement, than A. mellifera in the temperate zone, D.W. Roubik, unpublished data) were re-analyzed, and the general methods are described here (see also below). Pollen collected from 10 colonies of European honey bees in 1985-86 (Ceballos-Martínez, 1987), 5 in each site of our 1989-91 study, was collected with the same design and pollen trap used in our study. We made three pollen slides for each colony sample using the acetolysis method (Villanueva-G., 1994). The pollen sampled by Ceballos-Martínez for a total of 16 months yielded 360 microscope slides. We identified pollen and its relative abundance, gauged by the number of slides on which a given pollen species was found, and made a general and comprehensive (non-transect) examination of slides. This historical data on honey bee pollen collection during the period before African honey bee arrival was primarily important for determining which plant species used by African honey bees in the common apiary experiments of 1989-91 were formerly included in the European honey bee diet, at the same sites. Because the original study did not monitor rate of pollen harvest, and did not include proportional sub-samples of trapped pollen for each hive, it could not be applied further for quantitative analysis.

\subsection{Laboratory procedure and computations}

The collected pollen load samples were dried at $45^{\circ} \mathrm{C}$ for $24-48 \mathrm{~h}$ until reaching constant weight and the final weight was recorded. A subsample of 10 to $20 \mathrm{~g}$ of pollen was taken from each sample, soaked 
in $20 \mathrm{~mL}$ of distilled water and stirred magnetically for $1 \mathrm{~h}$. The pollen was sonicated for $5 \mathrm{~min}$ at $24 \mathrm{kHz}$ using a probe 'ultrasonic disintegrator' (M.S.E. SONIPREP) adjusted to medium power setting (O'Rourke and Buchmann, 1991). Then, Lycopodium clavatum spore tablets were added (13000 spores per tablet approximately) and mechanically mixed with the total pollen to serve as an internal calibration standard (Stockmarr, 1971) in order to estimate the absolute number of pollen grains in the total sample. The counts of Lycopodium spores, which are not foraged by bees, were used as a proxy for total pollen density in the prepared pollen slide. Applying this quantitative technique was necessary to determine bee diet, because it takes into account variance in pollen grain density among slides made from a single suspension, and among different samples. The total pollen volumes were computed for each species based upon transect counts, taken across the pollen slide with the aid of a reticule, by making systematic scans through a slide until 600 grains were identified, and then corrected for relative proportion of Lycopodium spores, and also by considering individual grain volumes (O'Rourke and Buchmann, 1991). Most pollen grains can be modeled as spheres, ellipses or prisms (O'Rourke and Buchmann, 1991). The mean longitudinal axis (p), and the mean equatorial axis (e) were obtained by measuring 10 pollen grains to calculate the pollen volumes as:

$$
\begin{gathered}
\text { sphere }=(1 / 6) \pi p^{3} \\
\text { ellipsoid }=(1 / 6) \pi \mathrm{e}^{2} p \\
\text { prism }=(1 / 4) s^{2} h \sqrt{3}
\end{gathered}
$$

where variables $p, e, s$ and $h$ are dimensions of the axes (O’Rourke and Buchmann, 1991).

Collected pollen from the simultaneous introduction experiments of 1989-91 was identified following Palacios-Chavez et al. (1992) and Roubik and Moreno (1991). Two or three slides were made for each sampled colony in each month, for a total of 144 colony samples from Palmas and 122 samples from Sian Ka'an. The general count of a species in a sample is given by:

$$
\mathrm{P}_{\mathrm{i}}=\mathrm{XLTN}
$$

where:

$\mathrm{P}=$ total pollen grains of species $\mathrm{i}$;

$\mathrm{X}=$ the mean number of spores in a Lycopodium tablet added to the sample;

$\mathrm{L}=$ the number of spore tablets added to the sample of pollen from which the slide was made;

$\mathrm{T}=$ the number of Lycopodium spores (grains) found in the transect of 600 grains;

$\mathrm{N}=$ the total pollen grains of species i recorded in the transect count of 600 grains.
The combined analysis gives an accurate estimate of the bee diet, completely unknown when solely considering numerical pollen grain abundance (Roubik, 1989; O'Rourke and Buchmann, 1991; Buchmann and O'Rourke, 1991). Quantitative comparison of pollen volumes harvested by the two honey bees was made using the Morisita-Horn (MH) similarity index (Southwood and Henderson, 2000, see also Nagamitsu et al., 1999). The index we applied to pollen volumes is given in the form:

$$
\mathrm{MH}=2 \Sigma\left(\mathrm{an}_{\mathrm{i}} \mathrm{bn}_{\mathrm{i}}\right) /(\mathrm{da}+\mathrm{db}) \mathrm{aN} \mathrm{bN}
$$

where:

$\mathrm{aN}=$ total pollen volume used by subspecies (a or b);

$\mathrm{an}_{\mathrm{i}}=$ the pollen volume in the ith species in the samples of subspecies ( $a$ or $b$ );

and

$$
\mathrm{da}=\Sigma \mathrm{an}_{\mathrm{i}}^{2} / \mathrm{aN}^{2} \text {. }
$$

This method avoids errors inherent to making comparisons in diet using an index like that of Shannon-Wiener (Southwood and Henderson, 2000). Such an inadequacy is amplified by differences in dominance and richness of species. In addition, we assessed an MH similarity in the intensity of pollen utilization by each honey bee race. That was done by considering the mean proportions of each pollen species harvested by colonies in one day.

We estimated the total pollen species used by each honey bee in the habitat using the Chao formula (Colwell, 1997). This estimate takes the form:

$$
\mathrm{N}_{\text {est }}=\mathrm{N}_{\mathrm{obs}}+\left(\mathrm{a}^{2} / 2 \mathrm{~b}\right)
$$

where:

$\mathrm{N}=$ total species richness (estimated and observed);

$\mathrm{a}=$ number of species observed only once;

$\mathrm{b}=$ number of species observed only twice;

and

$\mathrm{V}_{\text {est }}=\mathrm{b}\left[(\mathrm{a} / \mathrm{b} / 4)^{4}+(\mathrm{a} / \mathrm{b})^{3}+(\mathrm{a} / \mathrm{b} / 2)^{2}\right]$

where:

$\mathrm{V}_{\mathrm{est}}=$ variance of the estimator.

To obtain the Chao estimate, in particular the number of resources sampled only once or twice, we analyzed individual colony samples of each pollen species.

\section{RESULTS}

Pollen use by African and European bees in Yucatan is ranked in Figures 1-3 and Tables I and II. A total of 2938 pollen species-colony samples were quantified for pollen volumes, 


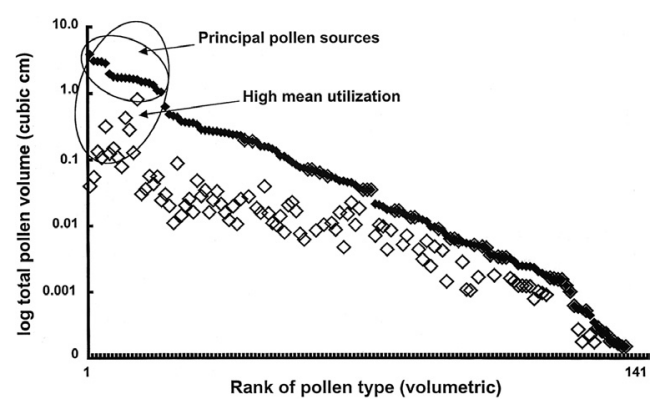

Figure 1. Pollen volumes harvested, and harvest intensity, during two years by European honey bees in experimental apiaries in Sian Ka'an biosphere reserve and adjacent forest, Quintana Roo, Yucatan Peninsula. Ranked volumes of pollen types are shown by solid symbols; mean volumes harvested colony $^{-1}$ month $^{-1}$ are open symbols.

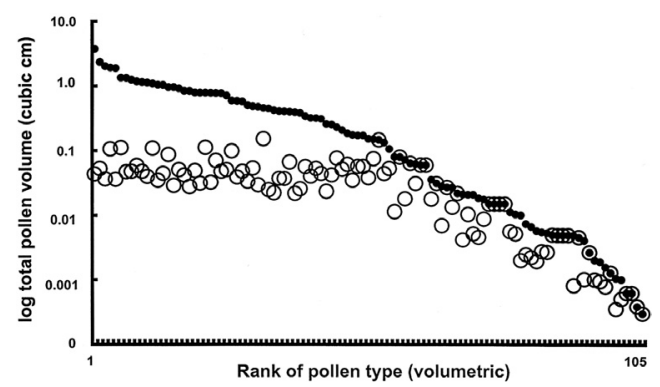

Figure 2. Pollen use during two years by African honey bees in the experimental apiaries; details are as in Figure 1.

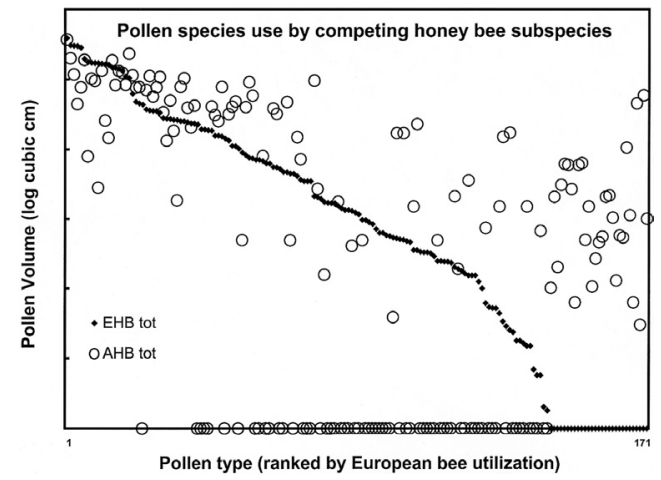

Figure 3. Comparative pollen preference by invasive African and non-invasive European honey bees studied simultaneously for two years at Sian Ka'An Biosphere reserve and a nearby site. Ranked volumes of pollen types used by the European bees are shown by solid symbols. Pollen types exploited by the African bees and their hybrids are open symbols; those exploited by one and not by the other appear along the $\mathrm{X}$ axis.
Table I. Principal pollen sources used by two honey bees, ranked by total harvested pollen volume (cubic $\mathrm{cm}$ ) quantified from pollen slides, at two sites in Quintana Roo, Mexico (1989-91). EHB = European honey bees, AHB = African hybrid honey bees.

\begin{tabular}{ll}
\hline AHB Top 22 species & EHB Top 22 species \\
\hline Cecropia peltata & Cecropia peltata \\
Eugenia sp. 1 & Trema micrantha \\
Trema micrantha & Panicum sp. 1 \\
Coccoloba sp. 1 & Cordia sp. 4 \\
Bursera simaruba & Cayaponia sp. 1 \\
Dendropanax arboreus & Coccoloba sp. 1 \\
Pouteria sp. 1 & Palmae sp. 1 \\
Mimosa bahamensis & Pluchea sp. 1 \\
Panicum sp. 1 & Eupatorium albicaule \\
Hibiscus sp. 2 & Chloris sp. 1 \\
Pseudobombax ellipticum & Dendropanax arboreus \\
Amphilophium panicula- & Cydista sp. 2 \\
tum & \\
Parthenium hysterophorus & Zea mays \\
Pluchea sp. 1 & Bursera simaruba \\
Paspalum sp. 1 & Thouinia canesceras \\
Eupatorium albicaule & Pouteria sp. 1 \\
Rhynchospora microcarpa & Mimosa bahamensis \\
Bidens sp. 1 & Bidens sp. 1 \\
Thouinia canesceras & Eugenia sp. 1 \\
Eragrostis sp. 1 & Hibiscus sp. 2 \\
Metopium brownei & Leucaena leucocephala \\
Hibiscus sp. 1 & Metopium brownei \\
\hline &
\end{tabular}

including roughly 400 thousand grains. Similar results at the two sites allowed combined analysis. Of 171 species, only 21 were recorded in multiple colonies at one site while absent at the other. Three times as many unique species recordings occurred at the Sian Ka'an site, compared to Palmas, although the number of species-colony samples were nearly identical (1474 versus 1464).

Aside from sharing the most important pollen types (Villanueva-G., 1999, 2002, and Tab. I), diets of the two honey bee subspecies were dissimilar (Figs. 1-3, and refer to VillanuevaG.,1994, 1999, for the complete species lists). In general, frequent collection of a given species did not imply diet importance, but the correlation was positive for the most heavily used pollens. Individual colonies most frequently collected pollen of Cecropia peltata, Trema micrantha, and Bursera simaruba, with the number of colony samples containing these species totaling 108, 102 and 111, respectively. 
Table II. Recorded and estimated total pollen species utilized by African honeybees (and hybrids) compared to European honeybees at two forest sites for two years in Quintana Roo, Mexico. Chao estimates were derived considering the species sampled only once or twice by any colony (see Methods).

\begin{tabular}{lcccc}
\hline Honeybee race & No. species recorded & \multicolumn{3}{c}{ Chao estimate of species richness } \\
\cline { 3 - 5 } & & No. once & No. twice & Estimate \\
\hline European & 141 & 45 & 20 & 192 s.d. 16 \\
African & 105 & 25 & 13 & 129 s.d. 10 \\
\hline
\end{tabular}

By their volumes, these species also were the most important pollen sources (Tab. I).

The quantitative similarity in diet between African and European bees was given by the Morisita-Horn (MH) index as 0.76. Considering exploitation intensity for individual pollen sources, an MH similarity of 0.55 was obtained. The open symbols in Figures 1 and 2 graphically represent the latter comparison, while Figure 3 depicts the difference in pollen species, and volume harvested, by the two bees.

The Chao estimate of total pollen species utilized by each bee in the combined study sites was calculated as 129 , s. d. $=10$ for African honey bees, and 192, s. d. $=16$ for European honey bees (Tab. II).

European bees concentrated more heavily on fewer species and used their most important species more than did African bees $(P=0.02$, $t$-test). They collected $82 \%$ of all pollen from 22 plants - species also abundant in the African bee diet (Tab. I) - but contributing only $57 \%$ of their total volume. The top 22 species for African bees accounted for $62 \%$ of pollen diet (Tab. I). No statistical differences were found in the mean pollen volumes harvested by the two bee races when all 171 plant species were included, but means for the top 22 species of each differed substantially (paired t-tests, onetailed, $P=0.47$ and 0.02 , respectively). The flat curve of open symbols on the left in Figure 2 indicates the Africanized honey bees exploited their most important resources in an equable manner, while the corresponding curve for European honey bees (Fig. 1) consistently shows peaks for the most important resource species.

Despite the relative specialization in important diet items by European honey bees, they used many unique species and had a 37\% larger diet breadth than African honey bees. Sixtyfour of the 141 pollen types (45\%) recorded for
European honey bees were not collected by African bees, while the latter visited 105 species, $27(26 \%)$ not visited by European bees (Fig. 1). The maximum number of species used during one month at combined sites was 65 for the European bees and 55 for the African bees in 1989-91. This was in a drought period, when flowers were very scarce.

The most important pollen source in our simultaneous comparison of honey bees had previously been unexploited. Cecropia peltata, an abundant secondary growth tree with nectarless flowers, was lacking in the diet of European honey bees in 1985-86. Only a few grains were encountered on three microscope slides. In contrast, pollen of this pioneer tree became the single most important resource for all Apis mellifera (Villanueva-G., 1999). Bees in both sites used Cecropia, but the European bee did so relatively more at Palmas (contingency table test, $P<0.001)$. This plant accounted for $10 \%$ of European and $15 \%$ of African honey bee pollen harvest, among our study colonies, during 1989-91. The pollen was collected only in November in the 1985-86 study. During our later study, Cecropia pollen occurred in $94 \%$ of European and $83 \%$ of Africanized honey bee pollen samples, through most of each year (Villanueva-G., 1999).

Considering the significant pollen sources, an order-of-magnitude lower exploitation by African honey bees (Tab. I) compared to their European competitors, occurred at grasses (Panicum, Zea, Chloris), trees (Cordia, one palm), two vines (Cayaponia, Thouinia) and the composite herbs Pluchea and Eupatorium. In contrast, African bees displayed complete dominance at one sedge (Rhynchospora), two grasses (Paspalum, Eragrostis), two trees (Pseudobombax, Pouteria) one vine (Amphilophium) and a shrub (Hibiscus). 
Seven of the 27 species not foraged by European bees but used by African bees in our experiment had previously been harvested by the European bees, four of these intensively. Compared to June 1985-August 1986, the pollen flowers visited in Sian Ka'an during June 1989-May 1991 by European honey bees did not include Panicum sp. 2 (formerly collected in October), Cydista (October), one unidentified Cyperaceae (February), Bravaisia tubliflora (March), Psittacanthus mayanus (July), Leonotis nepetaefolia (June) and Euphorbia sp. (July). The first four species were abundant in monthly samples in 1985-86.

\section{DISCUSSION}

Pollen studies in which both species and their use are precisely quantified are not possible without the use of a pollen trap, replication, and accurate determination of grain volume (see Silveira, 1991). Nonetheless, morphospecies or species can be valuable information. The maximum number of species used during one month at combined sites was 65 for the European bees and 55 for the African bees in 1989-91. This was a drought period, when flowers were scarce. In prolonged drought during the study period of 1985-86 rainfall decreased nearly $20 \%$ below the mean for 36 years; it was $996 \mathrm{~mm}$, compared to $1244 \mathrm{~mm}$ and $1207 \mathrm{~mm}$ in June-May for 1985-86, 198990 and 1990-91, respectively (Villanueva-G., personal observation). Interestingly, during this time no more than 15-22 species were harvested monthly by European honey bees in two localities, before the colonization of southern Mexico by African bees, including our forested sites at Sian Ka'An (Villanueva-G., 1984; Ceballos-Martínez, 1987). The earlier studies used five to eight colonies to produce monthly samples, thus bias results toward greater taxonomic diet breadth. Because relatively narrow pollen specialization by African and European bee colonies was documented in both Mexico and Panama before there was an established feral population of Apis mellifera (VillanuevaG., 1984; Roubik, 1988, 1992), the 'saturation' of the environment with invasive honey bees (Tokeshi, 1999) appears to have led to greater variety in resource use. Our analysis of both a drought year and two normal years imply com- petitive pressures interacting with resource scarcity strongly affected floral choice and pollen harvest by the bees.

In 1985-86 Cecropia peltata, an abundant secondary growth tree with nectarless flowers, was lacking in the diet of European bees. During 1989-91 this pioneer tree had not increased in abundance (no clearing of forest or new edge habitats had appeared) but was the single most important post-invasion pollen source of all Apis mellifera (Villanueva-G., 1999). As indicated by the pollen data, the resource was steadily available, whereby it totaled $10 \%$ of European and $15 \%$ of African honey bee diets. Pollen was collected only in November in the 1985-86 study. During our later study, Cecropia pollen occurred in 94\% of European and 83\% of African honey bee pollen samples (Villanueva-G., 1999). Cecropia has flowers primarily during the wet season (Villanueva-G., Roubik, personal observations). We suspect that flowering by Cecropia was diminished by drought in 198687 , but believe the complete readjustment of honey bee diet to make this nectarless species the single most important tree, when nectarbearing flowering trees are normally much more important in honey bee diets (Roubik, 1989) suggests a shift in floral preference, and possibly the acceptance of pollen of inferior nutritional quality.

The historical data strongly suggest competitive displacement. Seven of the 27 species not foraged by European bees but used by African bees in our experiment had previously been harvested by the former European bees of Yucatán apiaries, four of these intensively (Ceballos-Martínez, 1987 and present re-analysis). Compared to June 1985-August 1986, the pollen flowers visited in Sian Ka'an during June 1989-May 1991 by European honey bees did not include Panicum sp. 2 (formerly collected in October), Cydista (October), one unidentified Cyperaceae (February), Bravaisia tubliflora (March), Psittacanthus mayanus (July), Leonotis nepetaefolia (June) and Euphorbia (July). The first four species were abundant in monthly samples during 1985-86.

Experiments that propose to study impact of invasive honey bees ideally include introduction of hundreds of colonies, but have not been carried out (Roubik, 1978, 1983, 1989, 1996a, b; Roubik et al., 1986; Roubik and Wolda, 2001; Steffan-Dewenter and Tscharntke, 2000). 
Estimates of African honey bee colony densities in the Yucatán peninsula of Mexico exceed the diminutive presence of the temperate honey bees in northern forest (Seeley, 1985) by an order of magnitude (Ratnieks et al., 1991). Thus the required spatial scale, the need for thousands of honey bee colonies in introduction-removal experiments, and the necessity for replication, pose significant difficulties for communitylevel study. When we introduced two geographic races of one species to a common experimental area that was already filled with honey bees nesting in the wild, potential competition became extreme. Only slight differences generally exist between geographic variations of one species, compared to different species. Therefore, aspects of competition should be brought to the fore and sustained more clearly than between less closely matched competitors. Pollen resources of locally-adapted (Mexican) European honey bees, and re-introduced European bees before and after African bees arrived suggest competition from an invasive honey bee caused the former apiary resident bees to (1) abandon former resources (competitive displacement), (2) use fewer resources intensively (diminished diversity - increased specialization), and (3) add resource taxa (niche expansion). Our study could not replace the original honey bee of Yucatan, which had an approximately 70 -year history of domestication in the region and mixed origin of two subspecies; the bee was slightly smaller than the European honey bee in the temperate zone (not a feral species, see Clarke et al., 2001; Roubik and Villanueva, unpublished data). However, our tests using imported A. m. ligustica should serve as a close approximation to the ancestral, competing European honey bees that have now been extirpated from the area, but were never a presence in natural habitats outside of apiaries there (Clarke et al., 2002).

European bees intensively harvested most of their pollen from the same plants exploited intensively by the African bees. This suggests competitive parity or superiority to the invasive subspecies. The European bees also used their major resources less evenly than did the African bees. The Shannon-Wiener estimate H' was 1.56 for European bees and 1.67 for the Africanized bees, but this index routinely fails completely as a comparative diversity index because it emphasizes species with medium abundances, rather than those that are very abundant or rare - like most pollen sources that we recorded (Southwood and Henderson, 2000). Such an index would obscure large differences noted between the two bees (Tabs. I and II, Figs. 1-3). The evenness of resource use is, however, a positive correlate of resource diversity, as reflected in adequate indices of species diversity such as Simpson's diversity, or the index we applied (Morishita, 1967) versus species richness alone (e.g. Southwood and Henderson, 2000).

In our study of two honeybee subspecies, the greater generalist has enjoyed greater success as a colonist, although many other traits, including defensive and absconding ability, help explain the success of the African honey bee (e.g. Roubik, 1989; Spivak, 1992). Our data provide the first explanation for the observed greater pollen harvesting capacity of African honey bee colonies compared with European apiary bees in the same place (Danka et al., 1987; Fewell and Bertram, 2002). The African bees exploit more flower species in a significant way, rather than merely sample them. That difference was particularly striking because the European honey bee used many more resource species than did African bees, but used fewer to a significant degree. The expected result is less pollen income, on average.

One problem arises in establishing generality of this result, because it is based on behavior that involves plant species abundance, competitor abundance, and also bee genotype (Oldroyd et al., 1993; Fewell and Page, 2000). Which, if any, was most important? The African honey bees must compete with themselves, and all previous work, including our own, has been made using apiaries surrounded for many kilometers by thousands of competing, feral African honey bee colonies. If only a few African bee colonies were surrounded by many European colonies, different results might be obtained. In the setting of forested Quintana Roo, where neither of the two honey bees is native and therefore neither should have a competitive edge exploiting flowers, we believe the European honey bee was forced to specialize on fewer species, and also to attempt using many species for which it could not compete or did not find in sufficient abundance to specialize upon. In other words, diet diversity decreased and specialization increased as a function of 
competitive intensity. Although normally applied to interspecific competition (Tokeshi, 1999) this concept seemed to fit competition between the tropical and temperate honey bee races. What about plant abundance? The same flower species were generally available throughout the study, but the relative abundance of flowers like those of Cecropia that normally occur during the rains was limited in the 198586 study and also in part of the latter study due to drought. It is, however, not anticipated that a pollen source used by one variety of European honey bee (in 1985-86) would not be used by another variety of that bee (1989-91), but exploited instead, exclusively, by African honey bees. That this was a result of competitive displacement seems much more plausible and is the interpretation suggested here. What aspects of resource use were due to differing genetic composition of competitors? We have no information. However, our data could be used to dispute the concept that genetics play a major role either in honey bee selection of flower species or in predicting food niche richness as a correlate of genetic richness among consumers (the imported European bees in 1989-91 were likely far less diverse than the hybrid European-African bees that we studied in 1989-91).

Both bees exploited the same wide variety of floral types and plant life forms (see also Villanueva-G., 1994, 1999). African bees may have competitive advantage harvesting from trees, grasses and sedges such as Pseudobombax, Paspalum and Rhynchospora which are utilized heavily at dawn when pollen is available (Roubik, 1978; Danka et al., 1987; Roubik and Wolda, 2001) due to having a higher general metabolism (Heinrich, 1979). This would permit slightly earlier activity. Neither honey bee forages aggressively by attacking other species, but the Africanized honey bee does briefly skirmish with the same subspecies at pollen flowers (Roubik, 1978 and unpublished data).

As African honey bees filled tropical America, where honey bees formerly nested exclusively in apiaries, our studies suggest the diet breadth and resource use of non-invasive European honey bees, and moreover the native bees, are readily modified by competition with the novel, invasive tropical bees. We further conclude that multi-year replication and habitat saturation by exotic honey bees are necessary to determine their impact, and that quantitative palynological analysis should be applied more frequently to environmental questions related to bees.

\section{ACKNOWLEDGMENTS}

We thank El Colegio de la Frontera Sur, CONACYT and STRI for financial support, and W. ColliUcán, the late R. Palacios-Chávez and B. LudlowWiechers for assistance. We also thank Dr. S.J. Wright and Dr. G. Islebe for comments on a draft of this paper.

Résumé - Pourquoi les abeilles (Apis mellifera) africaines, et pas les européennes, sont-elles invasives ? Diversité du régime pollinique dans des expériences communes. Nous avons étudié l'utilisation des ressources et la compétition entre races d'abeilles domestiques (Apis mellifera L.) en réintroduisant la race européenne $A$. $m$. ligustica dans des ruchers exprimentaux situés dans un habitat saturé par les abeilles africaines (A. m. scutellata) (ou les hybrides africaines $\mathrm{x}$ européennes) qui avaient colonisé naturellement les forêts de la péninsule du Yucatan (Mexique). L’étude a été menée dans la réserve de biosphère de Sian Ka'An, qui comporte un demi million d'ha de basses terres couvertes de forêts à feuilles semi-caduques de petite taille, et dans la principale zone apicole des Mayas. Les trappes à pollen du collège agricole de l'Ontario ont été placées sur des ruches choisies au hasard. Chaque mois nous avons récolté le pollen durant une journée entière à chacun des deux ruchers et chaque mois nous avons échantillonné trois colonies, sur un total de 30 colonies d'abeilles européennes et africanisées élevées en nombre égal sur les deux sites. Plus de 171 espèces polliniques ont constitué le régime alimentaire des abeilles. Le pollen a été acétolysé et mélangé avec une pastille de spores de lycopode pour servir de calibration interne, puis mesuré, déterminé et identifié. Environ 400000 grains ont été identifiés et leur volume absolu a été estimé à partir des dimensions mesurées des grains dans des échantillons.

L'indice de similitude Morisita-Horn (similitude maximum $=1,0$ ) entre les deux races a été de 0,76 pour l'utilisation du pollen et, calculé à partir de l'utilisation journalière moyenne en volume par les colonies de chaque race, de 0,55 pour l'intensité d'utilisation spécifique d'un taxon. On a montré que les autres indices de diversité ou de similitude étaient inappropriés, par exemple l'indice H' de ShannonWiener, parce que peu d'espèces communes et beaucoup d'espèces rares caractérisaient le régime des deux races. Bien qu'utilisant un plus grand nombre d'espèces végétales, les abeilles européennes se sont spécialisées sur quelques plantes beaucoup plus fortement que les abeilles africaines. En ré-analysant 
les pelotes de pollen récoltées pendant une année avec les mêmes trappes à pollen avant l'arrivée des abeilles invasives sur les deux même sites expérimentaux par les abeilles européennes localement adaptées (abeilles mexicaines), après identification selon leur couleur, nous en concluons que les abeilles locales peuvent réagit à la compétition d'abeilles domestiques exotiques en choisissant d'autres fleurs et en augmentant la spécialisation des ressources. Nous attestons plusieurs changements prédits par la compétition alimentaire intense sans interaction agressive : changement dans les principales espèces utilisées (substitution du pollen anémophile de Cecropia comme principal élément du régime), faible diversité du régime et uniformité chez les abeilles européennes, abandon par les abeilles européennes de 7 espèces végétales en raison de la compétition. Le caractère général des résultats est discuté en termes d'abondance relative des abeilles domestiques dans un environnement où elles ne sont pas indigènes. L'identification quantitative et qualitative des pelotes de pollen a permis de montrer que les abeilles africanisées utilisaient leurs principales ressources de façon plus régulière que les abeilles européennes, ce qui leur confère un plus grand succès dans la colonisation en maintenant des rentrées de pollen plus importantes. Nous montrons comment l'analyse pollinique quantitative répétée peut constituer un outil puissant pour comprendre la diversité des régimes alimentaires des abeilles, ainsi que l'écologie et la dynamique de la récolte des ressources florales.

Apis mellifera / régime alimentaire / diversité / utilisation de la niche / espèce invasive / compétition alimentaire / analyse pollinique

\footnotetext{
Zusammenfassung - Warum sind afrikanische, aber nicht europäische Bienen invasiv? Diversität der Pollennahrung in kommunalen Experimenten. Wir untersuchten die Ressourcennutzung und den Wettbewerb zwischen Varietäten der Honigbiene (Apis mellifera L.), indem wir Bienenstände von europäischen $A$. $m$. ligustica in einem mit afrikanischen (oder afrikanisch-europäischen Hybriden) Bienen „saturierten“ Habitat wieder einführten. Diese hatten zuvor die Waldgebiete der Halbinsel von Yukatan natürlich besiedelt. Die Arbeiten wurden innerhalb der Region des Sian Ka' Biosphärenreservates ausgeführt, das sich in der Hauptbienenhaltungszone der Maya befindet und eine halbe Million ha Tiefland-Halblaubwald niedriger Höhe umfasst. Wir befestigten Ontario Collage Pollenfallen an zufällig ausgewählten Bienenvölkern und sammelten jeden Monat an zwei experimentellen Bienenständen jeweils einen ganzen Tag lang Pollen. Es wurden jeden Monat 3 Völker von insgesamt 30 Völkern europäischer und afrikanischer Bienen besammelt, die in gleichen Anzahlen an zwei Standorten
}

unterhalten wurden. Hieraus ergaben sich mehr als 170 aus Pollenarten zusammengesetzte Nahrungen. Der Pollen wurde acetolysiert, mit einem internen Eichstandard von Schachtelhalmsporen gemischt, vermessen, beschrieben und identifiziert. Etwa 400000 Pollenkörner wurden identifiziert und ihr absolutes Volumen in den Proben aus den ermittelten Körnergrößen abgeschätzt. Der Ähnlichkeitsindex von Morisita-Horn (Größte Ähnlichkeit = 1,0) zwischen den Honigbienenrassen betrug 0,76 für die Pollennutzung und, errechnet aus der mittleren täglichen Volumennutzung der Völker der zwei Subspezies, 0,55 für die taxonspezifische Intensität der Nutzung. Andere Indizes der Diversität oder Ähnlichkeit e.g. Shannon-Wiener H', waren nicht anwendbar, da beide Pollennahrungen durch einige wenige allgemeinverbreitete und viele seltene Pollenspezies die Nahrungen kennzeichneten. Obwohl sie mehr verschiedene Pflanzenspezies nutzten, spezialisierten sich die europäischen Bienen stärker auf einige wenige Pflanzen als die afrikanischen Bienen. Durch eine Nachanalyse von ein Jahr lang an den selben Standorten mit den gleichen Pollenfallen vor der Ankunft der invasiven Honigbienen in Südmexiko von durch lokal adaptierte (mexikanische) europäische Bienen gesammeltem Pollen (der zuvor auf der Basis der Farbe identifiziert worden war) leiten wir $\mathrm{ab}$, dass die lokalen Bienen auf die Konkurrenz der exotischen Bienen durch eine Verlagerung der Blütenwahl und Erhöhung der Ressourcenspezialisierung reagieren. Wir dokumentieren verschiedene Veränderungen, die durch intensive Futterkonkurrenz ohne aggressive Interaktionen vorausgesagt werden: Änderungen der genutzten Hauptspezies (Ersatz des windbestäubenden Cecropia Pollens als hauptsächliche Futterkomponente), niedrige Diversität der Futterpartikel und niedrige Evenness bei den europäischen Bienen, und offensichtliche kompetitive Verdrängung bei sieben Blütenarten, die von den europäischen Bienen aufgegeben wurden. Wir diskutieren die Verallgemeinerungsfähigkeit der Ergebnisse in Beziehung zu der relativen Häufigkeit des Vorkommens der Honigbienen in einer nicht-einheimischen Umgebung. Durch die Bestimmung der Menge und Herkunft der Pollenladungen konnten wir ermitteln, dass die afrikanisierten Honigbienen ihre hauptsächlichen Ressourcen gleichmäßiger nutzten als die europäischen Honigbienen. Dies könnte ihnen ermöglichen, einen höheren Polleneintrag im Volk aufrecht $\mathrm{zu}$ erhalten und hierdurch erfolgreichere Kolonisten zu sein. Wir konnten aufzeigen, dass eine wiederholte quantitative Pollenanalyse ein mächtiges Werkzeug sein kann, wenn sie zum Verständnis der Diversität der Bienennahrung und der Ökologie und Dynamik der Besammlung floraler Ressourcen angewandt wird.

\section{Apis mellifera / Nischennutzung / Nahrungsdiversität / Pollen / invasive Spezies / Konkurrenz}




\section{REFERENCES}

Agrawal A.A. (2001) Phenotypic plasticity in the interactions and evolution of species, Science 294, 321-326.

Banda A.S.M. (1989) Determining sources of forage for bees in Malawi through the identification of pollen in Malawian honeys, MSc Thesis, Bee Research Unit, University of Wales College of Cardiff, Cardiff, UK, 185 p.

Buchmann S.L., O’Rourke M.K. (1991) Importance of pollen grain volumes for calculating bee diets, Grana 30, 591-595.

Ceballos-Martínez V.M. (1987) Evaluación del polen recolectado por la abeja Apis mellifera ligustica Spinola en la Reserva de la Biosfera de Sian Ka'an, Quintana Roo, México. Thesis, Universidad Veracruzana, Córdoba, Veracruz, Mexico.

Clarke K.E., Oldroyd B.P., Quezada-Euán J.G., Rinderer T.E. (2001) Origin of honeybees (Apis mellifera $\mathrm{L}$.) from the Yucatan peninsula inferred from mitochondrial DNA analysis, Mol. Ecol. 10, 1347-1355.

Clarke K.E., Rinderer T.E., Franck P., Quezada-Euán J.G., Oldroyd B.P. (2002) The Africanization of honeybees (Apis mellifera L.) of the Yucatan: a study of a massive hybridization event across time, Evolution 56, 1462-1474.

Colwell R.K. (1997) EstimateS: Statistical estimation of species richness and shared species from samples. Version 5. User's Guide and application published at: http://viceroy.eeb.uconn.edu/estimates (checked on 20 July 2004).

Danka R.G., Hellmich II R.L., Rinderer T.E., Collins A.M. (1987) Diet-selection ecology of tropically and temperately adapted honeybees, Anim. Behav 35, 1858-1863.

Dick C. (2001) Genetic rescue of remnant tropical trees by an alien pollinator, Proc. R. Soc. London B 1781, 2391-2396.

Fewell J.H., Page R.E. Jr. (2000) Colony-level selection effects on individual and colony foraging task performance in honeybees, Apis mellfiera L., Behav. Ecol. Sociobiol. 48, 173-181.

Fewell J.H., Bertram S.M. (2002) Evidence for genetic variation in worker task performance by African and European honey bees, Behav. Ecol. Sociobiol. 52, 318-325.

Goulson D. (2003) Effects of introduced bees on native ecosystems, Annu. Rev. Ecol. Syst. 34, 1-26.

Heinrich B. (1979) Thermoregulation of African and European honeybees during foraging, attack and hive exits and returns, J. Exp. Biol. 80, 217-229.

Hepburn H.R., Radloff S.E. (1998) Honeybees of Africa, Springer-Verlag.

Morishita M. (1967) The seasonal variation of butterflies in Kyoto, in: Morishita M., Kira T. (Eds.), Natural-ecological study Cyuokoronnsha, Tokyo, pp. 95-132 (in Japanese).

Nagamitsu T., Momose K., Inoue T., Roubik D.W. (1999) Preference in flower visits and partitioning in pollen diets of stingless bees in an Asian tropical rain forest, Res. Pop. Ecol. 41,195-202.

O’Rourke M.K., Buchmann S.L. (1991) Standardized analytical techniques for bee-collected pollen, Environ. Entomol. 20, 507-513.

Oldroyd B., Rinderer T.E., Buco S.M., Beaman L.D. (1993) Genetic variance in honeybees for preferred foraging distance, Anim. Behav. 45, 323332.

Palacios-Chavez R., Ludlow-Wiechers B., VillanuevaG. R. (1992) Flora palinológica de la reserva de la biosfera de Sian Ka'an, Quintana Roo, Mexico. Quintana Roo, Mexico: Centro de Investigaciones Quintanrroenses.

Peterson A.T. (2003) Predicting the geography of species invasions via ecological niche modeling, $\mathrm{Q}$. Rev. Biol. 78, 419-433.

Ramalho M., Kleinert-Giovannini A., Imperatriz-Fonseca V.L. (1990) Important bee plants for stingless bees (Melipona and Trigonini) and Africanized honeybees (Apis mellifera) in Neotropical habitats: a review, Apidologie 21, 469-488.

Ratnieks F.L.W., Piery M., Cuadriello I. (1991) The natural nest of the Africanized honey bee (Hymenoptera, Apidae) near Tapachula, Chiapas, Mexico, Can. Entomol. 123, 353-359.

Ricciardelli D’ Albore G., Owusu M. (1994) Beekeeping and pollen spectra of some honeys from Ghana, Proc. Vth Int. Conf. on Apiculture in Tropical Climates, Trinidad and Tobago, 1992, IBRA, Cardiff, UK, pp. 106-109.

Rosenzweig M. (1995) Species diversity in space and time, Cambridge, New York, USA.

Roubik D.W. (1978) Competitive interactions between neotropical pollinators and Africanized honeybees, Science 201, 1030-1032.

Roubik D.W. (1983) Experimental community studies: time-series tests of competition between African and neotropical bees, Ecology 64, 971-978.

Roubik D.W. (1988) An overview of Africanized honeybee populations: reproduction, diet and competition, in: Needham G., Page R.E. Jr., DelfinadoBaker M. (Eds.), Africanized honeybees and bee mites, E. Horwood, Chichester, United Kingdom, pp. $45-54$.

Roubik D.W. (1989) Ecology and Natural History of Tropical Bees, Cambridge, New York.

Roubik D.W. (1992) Loose niches in tropical communities: why are there some many trees and so few bees? in: Hunter M.D., Ohgushi T., Price P.W. (Eds.), Effects of resource distribution on animalplant interactions, Academic, San Diego, pp. 327354.

Roubik D.W. (1996a) Measuring the meaning of honeybees, in: Matheson A., Buchmann S.L., O’Toole C., Westrich P., Williams I.H. (Eds.), The conservation of bees, Academic, London, pp. 163-172.

Roubik D.W. (1996b) African honeybees as exotic pollinators in French Guiana, in: Matheson A., Buchmann S.L., O'Toole C., Westrich P., Williams I.H. (Eds.), The conservation of bees, Academic, London, pp. 173-182. 
Roubik D.W. (2002a) The value of bees to the coffee harvest, Nature 417, 708 .

Roubik D.W. (2002b) Feral African bees augment Neotropical coffee yield, in: Kevan P.G., ImperatrizFonseca V.L. (Eds.), Pollinating bees: the conservation link between agriculture and nature, Ministry of Environment, Brazilia, Brazil, pp. 255266.

Roubik D.W. (2005) Honey bees in Borneo, in: Roubik D.W., Sakai S., Hamid A. (Eds.), Pollination ecology and the rainforest, Springer-Verlag, New York, pp. 212-224.

Roubik D.W., Moreno J.E. (1991) Pollen and spores of Barro Colorado Island, Monogr. Syst. Bot. 38. Missouri Botanical Garden, St Louis, Missouri.

Roubik D.W., Wolda H. (2001) Do competing honeybees matter? Dynamics and abundance of native bees before and after honeybee invasion, Pop. Ecol. 43, 53-62.

Roubik D.W., Schmalzel R., Moreno E. (1984) Estudio apibotanico de Panama: cosecha y fuentes de polen y nectar usados por Apis mellifera y sus patrones estacionales y anuales. Organismo internacional regional de sanidad agropecuaria (San Salvador, El Salvador), Bol. Tec. No. 24, 73 p.

Roubik D.W., Moreno J.E., Vergara C., Wittmann D. (1986) Sporadic food competition with the African honey bee: projected impact on neotropical social bees, J. Trop. Ecol. 2, 97-111.

Sakai A.K., Allendorf F.W., Holt J.S., Lodge D.M. et al. (2001) The population biology of invasive species, Annu. Rev. Ecol. Syst. 32, 305-332.

Seeley T.D. (1985) Honeybee ecology, Princeton University Press, Princeton.

Silveira F.A. (1991) Influence of pollen grain volume on the estimation of the relative importance of its source to bees, Apidologie 22, 495-502.

Smith F.G. (1956) Bee botany in Tanganyika, Ph.D. Thesis, University of Aberdeen, UK, 174 p.
Southwick E.E., Roubik D.W., Williams J.M. (1990) Comparative energy balance in groups of Africanized and European honey bees: ecological implications, Comp. Biochem. Physiol. A 97, 1-7.

Southwood T.R.E., Henderson P.A. (2000) Ecological methods, 3rd ed., Blackwell, Oxford.

Spivak M. (1992) The relative success of Africanized and European honey-bees over a range of lifezones in Costa Rica, J. Appl. Ecol. 29, 150-162.

Steffan-Dewenter I., Tscharntke T. (2000) Resource overlap and possible competition between honey bees and wild bees in central Europe, Oecologia 122, 288-296.

Stockmarr J. (1971) Tablets with spores used in absolute pollen analysis, Pollen Spores 13, 615-621.

Tokeshi M. (1999) Species Coexistence, Blackwell, Cambridge.

Villanueva-G. R. (1984) Plantas de importancia apícola en el ejido de Plan del Río, Veracruz, México, Biotica 9, 279-340.

Villanueva-G. R. (1994) Nectar sources of European and Africanized honeybees (Apis mellifera L.) in the Yucatán peninsula, Mexico, J. Apic. Res. 33, 44-58.

Villanueva-G. R. (1999) Pollen sources of European and Africanized honeybees in the eastern Yucatán Peninsula, Mexico, J. Apic. Res. 38, 105-111.

Villanueva-G. R. (2002) Polliniferous plants and foraging strategies of Apis mellifera (Hymenoptera: Apidae) in the Yucatán Peninsula, Mexico, Rev. Biol. Trop. 50, 1035-1044.

Wilms W., Imperatriz-Fonseca V.L., Engels W. (1996) Resource partitioning between highly eusocial bees and possible impact of the introduced Africanized honey bee on native stingless bees in the Brazilian Atlantic rainforest, Stud. Neotrop. Fauna Environ. 31, 137-151. 